Article

\title{
In situ DRIFTS study of the mechanism of low temperature selective catalytic reduction over manganese-iron oxides
}

\author{
Ting Chen, Bin Guan, He Lin*, Lin Zhu \\ Key Laboratory for Power Machinery and Engineering of Ministry of Education, Shanghai Jiao Tong University, Shanghai 200240, China
}

\section{A R T I C L E I N F O}

Article history:

Received 21 August 2013

Accepted 15 October 2013

Published 20 March 2014

Keywords:

Nitrogen Oxide

Ammonia

Manganese-iron catalysts

Low temperature selective catalytic reduction

In situ diffuse reflectance infrared

Fourier transform spectroscopy

\begin{abstract}
A B S T R A C T
To investigate the mechanism of selective catalytic reduction (SCR) of $\mathrm{NO}_{x}$ with $\mathrm{NH}_{3}$, $\mathrm{Ti}_{0.9} \mathrm{Mn}_{0.05} \mathrm{Fe}_{0.05} \mathrm{O}_{2-\delta}$ catalyst was prepared by self-propagating high-temperature synthesis (SHS) method and evaluated at $25-450{ }^{\circ} \mathrm{C}$. The catalyst was characterized by X-ray diffraction (XRD) and transmission electron microscopy (TEM). The possible SCR mechanism over $\mathrm{Ti}_{0.9} \mathrm{Mn}_{0.05} \mathrm{Fe}_{0.05} \mathrm{O}_{2-\delta}$ was studied by in situ diffuse reflectance infrared Fourier transform spectroscopy (DRIFTS). $\mathrm{Ti}_{0.9} \mathrm{Mn}_{0.05} \mathrm{Fe}_{0.05} \mathrm{O}_{2-\delta}$ showed both high SCR activity and $\mathrm{N}_{2}$ selectivity over a broad temperature window of $100-350^{\circ} \mathrm{C}$. The XRD and TEM results indicated that the active components of Mn and Fe were in a highly dispersed state and in an amorphous form on $\mathrm{TiO}_{2}$. The DRIFTS results revealed that Brönsted acid sites were the active centers for NO removal and monodentate nitrates were the key intermediate in the SCR reaction. At $150{ }^{\circ} \mathrm{C}$, both Langmuir-Hinshelwood and Eley-Rideal mechanisms are involved in the SCR reaction, while the former one mechanism dominates the catalytic activity of $\mathrm{Ti}_{0.9} \mathrm{Mn}_{0.05} \mathrm{Fe}_{0.05} \mathrm{O}_{2-\delta}$. Additionally, the presence of $\mathrm{O}_{2}$ significantly affects $\mathrm{NO}$ oxidation and coordinated $\mathrm{NH}_{3}$ activation.
\end{abstract}

(C) 2014, Dalian Institute of Chemical Physics, Chinese Academy of Sciences. Published by Elsevier B.V. All rights reserved.

\section{Introduction}

Nitrogen oxides $\left(\mathrm{NO}_{x}\right)$ are a major component of air pollution. Selective catalytic reduction (SCR) of $\mathrm{NO}_{x}$ with $\mathrm{NH}_{3}$ is a well-known promising technique for removing $\mathrm{NO}_{x}[1,2]$. The industrial catalysts for $\mathrm{NH}_{3}-\mathrm{SCR}$ usually comprise $\mathrm{V}_{2} \mathrm{O}_{5} / \mathrm{TiO}_{2}$ in combination with either $\mathrm{WO}_{3}$ or $\mathrm{MoO}_{3}$, however, there are also some disadvantages, such as the narrow operating temperature window $\left(300-400{ }^{\circ} \mathrm{C}\right)[3,4]$ and the environmental toxicity of vanadium species at high temperatures [5]. Therefore, novel high performance catalysts with transition metal alternatives to vanadium have been extensively investigated [6-11].

$\mathrm{Mn} / \mathrm{TiO}_{2}$ anatase catalyst reported by Ettireddy et al. [4] shows high activity for low temperature SCR of NO with $\mathrm{NH}_{3}$ and shows stable NO conversion and $\mathrm{N}_{2}$ selectivity, even after 10 days of time-on-stream in the presence of 11 vol\% water vapor at $175{ }^{\circ} \mathrm{C}$. However, the low temperature SCR performance of Mn-based catalysts is reduced by poisoning from sulfur residuals in fuels and engine oils. A series of catalysts composed of manganese oxide and iron-manganese oxide supported on $\mathrm{TiO}_{2}$ were studied for low-temperature SCR in the presence of excess oxygen. It was found that the addition of iron oxide not only increased the $\mathrm{NO}$ conversion and $\mathrm{N}_{2}$ selectivity but also increased catalyst resistance to $\mathrm{H}_{2} \mathrm{O}$ and $\mathrm{SO}_{2}$ [12].

Roy et al. [8] have prepared serial $\mathrm{Ti}_{0.9} \mathrm{M}_{0.1} \mathrm{O}_{2-\delta}(\mathrm{M}=\mathrm{Cr}, \mathrm{Mn}$, $\mathrm{Fe}, \mathrm{Co}$, and $\mathrm{Cu}$ ) catalysts using a self-propagating high-temperature synthesis (SHS) method. It was found that the optimum $\mathrm{Ti}_{0.9} \mathrm{Mn}_{0.05} \mathrm{Fe}_{0.05} \mathrm{O}_{2-\delta}$ catalyst showed good activity in the

\footnotetext{
* Corresponding author. Tel: +86-21-34207774; E-mail: linhe@sjtu.edu.cn This work was supported by the National Natural Science Foundation of China $(51176118,51306115)$ and the China Postdoctoral Science Foundation (2012M520894, 2013T60445).

DOI: 10.1016/S1872-2067(12)60730-X | http://www.sciencedirect.com/science/journal/18722067 | Chin. J. Catal., Vol. 35, No. 3, March 2014
} 
150-500 ${ }^{\circ} \mathrm{C}$ temperature range and more than $80 \% \mathrm{~N}_{2}$ selectivity even at $450{ }^{\circ} \mathrm{C}$. SCR catalysts prepared by the SHS method exhibited reasonably high specific surface areas, appropriate pore volumes, average pore diameters, and typical nanoparticle sizes [10], which significantly enhanced the catalyst performance.

The Mn-Fe based catalysts exhibit high activities at low temperature, which is possibly caused by the strong interactions of Fe and Mn. However, the SCR mechanism for this catalyst is still uncertain. For the Fe-Ce-Mn/ZSM-5 catalyst [13], two possible reaction pathways were proposed. One was that $\mathrm{NO}_{2}$ could react with $\mathrm{NH}_{4}{ }^{+}$on Brönsted acid sites and the formed $\mathrm{NO}_{2}\left[\mathrm{NH}_{4}{ }^{+}\right]_{2}$ would react with $\mathrm{NO}$, producing $\mathrm{N}_{2}$ and $\mathrm{H}_{2} \mathrm{O}$. Another pathway involves $\mathrm{NH}_{3}$ adsorption and subsequent reaction with $\mathrm{NO}$ or $\mathrm{HNO}_{2}$. Possible intermediates $\mathrm{NH}_{4} \mathrm{NO}_{2}$ and $\mathrm{NH}_{2} \mathrm{NO}$ were unstable and would decompose into $\mathrm{N}_{2}$ and $\mathrm{H}_{2} \mathrm{O}$. Additionally, the SCR reaction over $\left(\mathrm{Fe}_{2.5} \mathrm{Mn}_{0.5}\right)_{1-\delta} \mathrm{O}_{4}$ mainly follows an Eley-Rideal (E-R) mechanism [14]. Adsorbed ammonia species are activated to form amide species $\left(-\mathrm{NH}_{2}\right)$ by $\mathrm{Mn}^{4+}$ and $\mathrm{Fe}^{3+}$ on the surface. Then, gaseous $\mathrm{NO}$ is reduced by $-\mathrm{NH}_{2}$ on the surface to form $\mathrm{N}_{2}$ and $\mathrm{H}_{2} \mathrm{O}$. For the case of the $\mathrm{Ti}_{0.9} \mathrm{Mn}_{0.05} \mathrm{Fe}_{0.05} \mathrm{O}_{2-\delta}$ prepared by Roy et al. [8], according to a Langmuir-Hinshelwood (L-H) mechanism, the adsorbed $\mathrm{NH}_{3}$ or $\mathrm{NH}_{4}{ }^{+}$can react with adsorbed $\mathrm{NO}$ to form an $\mathrm{NH}_{2} \mathrm{NO}$ adduct, which can then dissociate into $\mathrm{N}_{2}$ and $\mathrm{H}_{2} \mathrm{O}$. Overall, the process of adsorption and activation of reactant $\mathrm{NH}_{3}$ or $\mathrm{NO}$ is important because it is related to the intermediate species and determines the reaction pathways.

The purpose of this study is to obtain information on the reaction mechanism of manganese and iron oxide catalysts at low temperatures through the respective adsorption of $\mathrm{NH}_{3}$ and $\mathrm{NO}$, as well as the reaction between $\mathrm{NH}_{3}$ and NO. SHS is an effective, low-cost method for production of various industrially useful materials [15]. In this paper, an SCR catalyst, $\mathrm{Ti}_{0.9} \mathrm{Mn}_{0.05} \mathrm{Fe}_{0.05} \mathrm{O}_{2-\delta}$ was also prepared by the SHS method [16]. The catalyst sample was exposed to simulated exhaust gas mixtures $\left(\mathrm{NO} / \mathrm{O}_{2} / \mathrm{NH}_{3} / \mathrm{N}_{2}\right)$ to evaluate the SCR performance and was characterized by in situ diffuse reflectance infrared Fourier transform spectroscopy (DRIFTS) to investigate the possible mechanism of $\mathrm{NH}_{3}$-SCR.

\section{Experimental}

\subsection{Catalyst preparation}

Catalyst $\mathrm{Ti}_{0.9} \mathrm{Mn}_{0.05} \mathrm{Fe}_{0.05} \mathrm{O}_{2-\delta}$ was prepared by the SHS method. First, the required amount of absolute alcohol was added dropwise into the precursor tetrabutyl titanate $\left(\mathrm{Ti}\left(\mathrm{OCH}_{3}\left(\mathrm{CH}_{2}\right)_{3}\right)_{4}\right)$, and deionized water was likewise added to the product of metatitanic acid $\left(\mathrm{TiO}(\mathrm{OH})_{2}\right)$. Next, in order to get titanyl nitrate $\left(\mathrm{TiO}\left(\mathrm{NO}_{3}\right)_{2}\right)$, the right amount of $\mathrm{HNO}_{3}$ solution was added. At the same time, a solution of metal nitrate $\left(\mathrm{Mn}\left(\mathrm{NO}_{3}\right)_{2} \cdot 4 \mathrm{H}_{2} \mathrm{O}\right.$ and $\left.\mathrm{Fe}\left(\mathrm{NO}_{3}\right)_{3} \cdot 9 \mathrm{H}_{2} \mathrm{O}\right)$ in deionized water was prepared in stoichiometric amounts. Then, the nitrate solution was combined with the titanyl nitrate. Glycine $\left(\mathrm{CH}_{2} \mathrm{NH}_{2} \mathrm{COOH}\right)$ was sequentially added to fuel the reaction. After stirring at 50 ${ }^{\circ} \mathrm{C}$ for $1 \mathrm{~h}$, the aqueous solution was placed in a muffle furnace at $350{ }^{\circ} \mathrm{C}$ in air. During the first few minutes, the solution boiled with froth and combusted with smoke. The resulting product was finally calcined at the ignition temperature for $1 \mathrm{~h}$. The synthesized catalyst was allowed to cool and was sieved to 40-80 mesh for further analysis.

\subsection{Catalytic activity tests}

Catalytic activity tests were carried out using the temperature-programmed reaction (TPR) method. The powder sample $(0.5 \mathrm{~mL})$ was used in a fixed-bed quartz reactor (i.d. $9 \mathrm{~mm})$, and the reaction temperature was raised from room temperature to $450{ }^{\circ} \mathrm{C}$ at a ramp rate of $5{ }^{\circ} \mathrm{C} / \mathrm{min}$. A simulated exhaust gas mixture $\left(0.06 \% \mathrm{NO}, 0.06 \% \mathrm{NH}_{3}, 5 \% \mathrm{O}_{2}\right.$, and $\mathrm{N}_{2}$ for balance) was fed to the catalyst sample through a set of mass flow controllers. The total flow rate was set to $100 \mathrm{~mL} / \mathrm{min}$, corresponding to a gas hourly space velocity (GHSV) of $12000 \mathrm{~h}^{-1}$. The outlet gas composition containing $\mathrm{NO}, \mathrm{NO}_{2}, \mathrm{~N}_{2} \mathrm{O}$, and $\mathrm{NH}_{3}$ was measured on-line with an FTIR gas analyzer (Thermo Nicolet 6700). Before the experiment, concentrations of the gases were quantified based on the classic least squares methodology using the Omnic Quantpad software. A calibration run of each gas consisting of four spectral absorption standards was performed and used to generate each standard curve within Quantpad.

\subsection{Catalyst characterization}

X-ray diffraction (XRD) was used to reveal the catalyst crystal phases. XRD continuous measurements were performed on a Rigaku D/max-2200/PC system. Diffraction patterns were obtained from $20^{\circ}$ to $90^{\circ}(2 \theta)$ with a scanning rate of $5^{\circ} / \mathrm{min}$, and a step size of $0.02^{\circ}$ at ambient temperature.

The microscopic morphology of catalyst was interrogated by transmission electron microscopy (TEM) on a JEOL JEM2010 analytical electron microscope operating at an accelerating voltage of $200 \mathrm{kV}$. Before TEM characterization, the catalyst powder was ultrasonically suspended in alcohol for $10 \mathrm{~min}$, after which the obtained suspension was deposited on copper-grid-supported amorphous carbon films. The impregnated mesh was allowed to dry in air for TEM analysis.

\subsection{In situ DRIFTS studies}

In situ DRIFTS spectra were measured by an FTIR gas analyzer (Thermo Nicolet 6700) equipped with a diffuse reflectance optics accessory (HVC-DRP-4). The inlet gas concentrations were identical to those used in the catalytic activity test $\left(0.06 \% \mathrm{NO}, 0.06 \% \mathrm{NH}_{3}, 5 \% \mathrm{O}_{2}\right.$, and $\mathrm{N}_{2}$ for balance). A $60 \mathrm{mg}$ of powder sample was used, and the total flow rate was 50 $\mathrm{mL} / \mathrm{min}$. To clean the catalyst surface, the sample was purged in $\mathrm{N}_{2}$ at $450{ }^{\circ} \mathrm{C}$ for $2 \mathrm{~h}$ prior to acquisition of DRIFTS spectra. Thereafter, the background spectra were recorded from 50 to $450{ }^{\circ} \mathrm{C}$, with $50{ }^{\circ} \mathrm{C}$ increments. In this experiment, the IR range was from 4000 to $650 \mathrm{~cm}^{-1}$, and the resolution was set to 4 $\mathrm{cm}^{-1}$.

\section{Results and discussion}




\section{1. $\mathrm{Ti}_{0.9} \mathrm{Mn}_{0.05} \mathrm{Fe}_{0.05} \mathrm{O}_{2-\delta}$ catalyst activity}

TPR was performed to evaluate the SCR performance of the $\mathrm{Ti}_{0.9} \mathrm{Mn}_{0.05} \mathrm{Fe}_{0.05} \mathrm{O}_{2-\delta}$ catalyst, as shown in Fig. 1 . The calculation methods to determine $\mathrm{NO}_{x}$ conversion, $\mathrm{N}_{2} \mathrm{O}$ selectivity, and $\mathrm{N}_{2}$ selectivity were described in our earlier paper [10]. More than $80 \%$ of $\mathrm{NO}$ is reduced by $\mathrm{NH}_{3}$ on the $\mathrm{Ti}_{0.9} \mathrm{Mn}_{0.05} \mathrm{Fe}_{0.05} \mathrm{O}_{2-\delta}$ catalyst in a wide temperature window of 100 to $350{ }^{\circ} \mathrm{C}$ (Fig. 1(a)). $\mathrm{Ti}_{0.9} \mathrm{Mn}_{0.05} \mathrm{Fe}_{0.05} \mathrm{O}_{2-\delta}$ reaches the maximum NO conversion of $100 \%$ at an especially low temperature of $120^{\circ} \mathrm{C}$, and this NO conversion rate remains at its peak until $350^{\circ} \mathrm{C}$. NO conversion subsequently decreases sharply above $350^{\circ} \mathrm{C}$. The main reason for this is unselective $\mathrm{NH}_{3}$ oxidation by $\mathrm{O}_{2}$. The $\mathrm{N}_{2}$ yield initially reaches over $95 \%$ at ambient temperature to $100{ }^{\circ} \mathrm{C}$, but then decreases to a lower level of around $70 \%$ at $250{ }^{\circ} \mathrm{C}$ (Fig. 1(b)). With further rise in temperature, the $\mathrm{N}_{2}$ yield again increases. From $350{ }^{\circ} \mathrm{C}, \mathrm{N}_{2}$ selectivity decreases monotonically due to oxidation of $\mathrm{NH}_{3}$. This can be seen from the $\mathrm{NO}_{2}$ concentration curve in Fig. 1(b). At the same time, under $250{ }^{\circ} \mathrm{C}, \mathrm{N}_{2} \mathrm{O}$ selectivity shows the reverse trend as $\mathrm{N}_{2}$ selectivity. A fast drop in selectivity happens between 250 and $300{ }^{\circ} \mathrm{C}$. $\mathrm{N}_{2} \mathrm{O}$ selectivity then decreases slightly with increasing temperature. Overall, in a broad temperature window of $100-350{ }^{\circ} \mathrm{C}, \mathrm{Ti}_{0.9} \mathrm{Mn}_{0.05} \mathrm{Fe}_{0.05} \mathrm{O}_{2-\delta}$ has high SCR activity, which is comparable to that reported by Roy et al. [8].

\subsection{Catalyst characterization}

The power XRD pattern of the $\mathrm{Ti}_{0.9} \mathrm{Mn}_{0.05} \mathrm{Fe}_{0.05} \mathrm{O}_{2-\delta}$ catalyst sample is shown in Fig. 2, with peaks indicated as identified in the ICDD (anatase $\mathrm{TiO}_{2}$ phase: PDF \#21-1272). The XRD peaks of the catalyst closely conform to anatase phase $\mathrm{TiO}_{2}$, with no evidence for the rutile phase. No diffraction peaks for $\mathrm{FeO}_{x}$, $\mathrm{MnO}_{x}$, or any other mixed oxides are seen, which indicates that

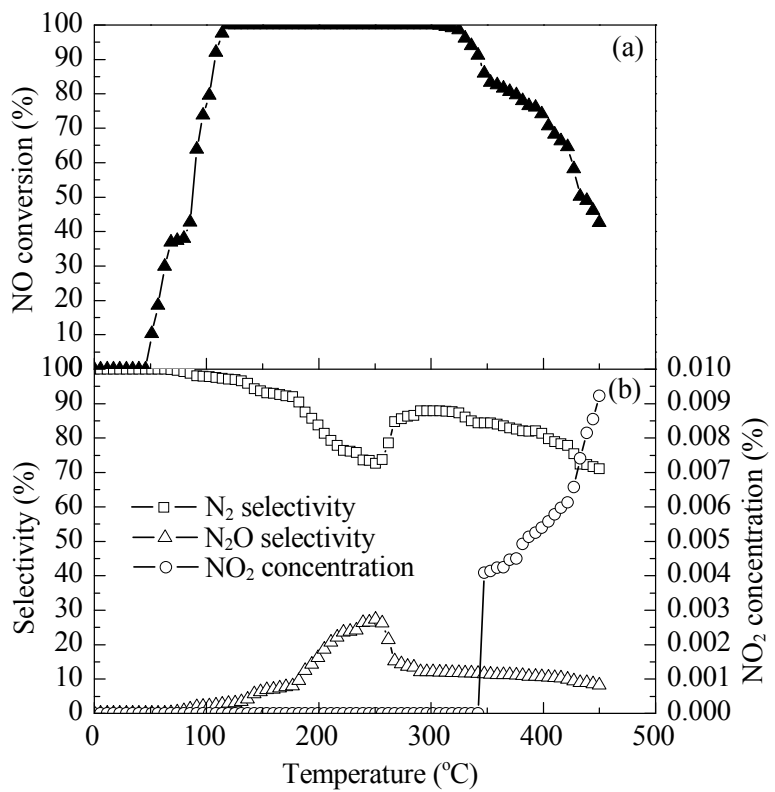

Fig. 1. $\mathrm{NO}$ conversion (a) and $\mathrm{N}_{2}$ selectivity, $\mathrm{N}_{2} \mathrm{O}$ selectivity, and $\mathrm{NO}_{2}$ concentration (b) over $\mathrm{Ti}_{0.9} \mathrm{Mn}_{0.05} \mathrm{Fe}_{0.05} \mathrm{O}_{2-\delta}$. Reaction conditions: $0.06 \%$ NO, $0.06 \% \mathrm{NH}_{3}, 5 \% \mathrm{O}_{2}, \mathrm{~N}_{2}$ as balance gas, total gas flow rate 100 $\mathrm{mL} / \mathrm{min}$, and GHSV $=12000 \mathrm{~h}^{-1}$.

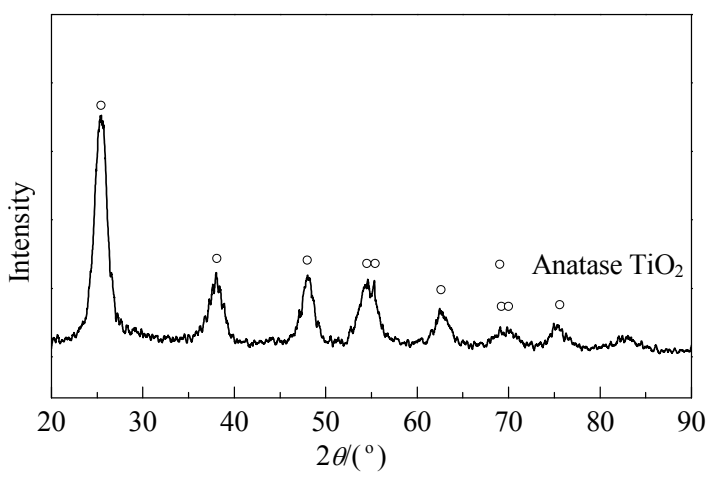

Fig. 2. Power XRD pattern of $\mathrm{Ti}_{0.9} \mathrm{Mn}_{0.05} \mathrm{Fe}_{0.05} \mathrm{O}_{2-\delta}$ catalyst.

the $\mathrm{Mn}$ and $\mathrm{Fe}$ are either in a highly dispersed state and assumes an amorphous form on $\mathrm{TiO}_{2}$, or that the formed crystallites cannot be detected by XRD. This is due to strong Fe-Mn interactions, which leads to enhanced dispersion and lower crystallization for both [12].

TEM was used to examine the morphology and size of the $\mathrm{Ti}_{0.9} \mathrm{Mn}_{0.05} \mathrm{Fe}_{0.05} \mathrm{O}_{2-\delta}$. As presented in Fig. 3, there are many nanoparticles dispersed on the catalyst, and no obvious particle agglomeration is apparent. The TEM image shows that the typical nanoparticles are well dispersed with sizes on the order of $10 \mathrm{~nm}$. At higher magnification, a crystal plane spacing of 0.346 $\mathrm{nm}$ is detected, which is slightly smaller than the spacing of the anatase $\mathrm{TiO}_{2}$ (101) plane. Any morphology of the manganese and iron oxides are not observed, which is consistent with the XRD result.

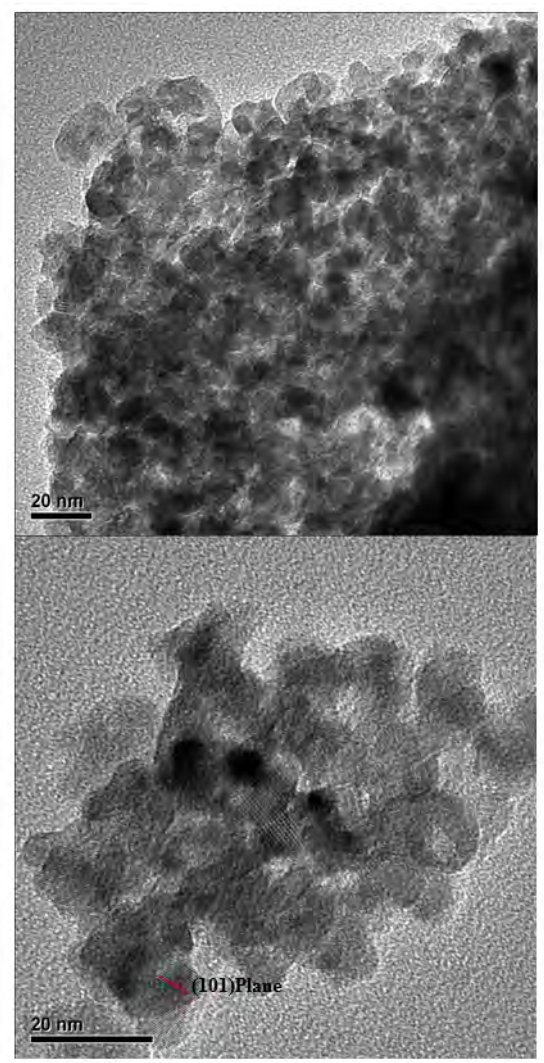

Fig. 3. TEM images of $\mathrm{Ti}_{0.9} \mathrm{Mn}_{0.05} \mathrm{Fe}_{0.05} \mathrm{O}_{2-\delta}$ sample. 


\subsection{In situ DRIFTS}

\subsubsection{Adsorption of $\mathrm{NH}_{3}$}

$\mathrm{NH}_{3}$ adsorption measurements were performed in a feed of $0.06 \% \mathrm{NH}_{3}$ in $\mathrm{N}_{2}$ at $50{ }^{\circ} \mathrm{C}$ for $30 \mathrm{~min}$. Catalyst Ti0.9 $\mathrm{Mn}_{0.05} \mathrm{Fe}_{0.05} \mathrm{O}_{2-\delta}$ was then purged with $\mathrm{N}_{2}$ for $30 \mathrm{~min}$. Surface adsorption species with IR bands at 1188 and $1598 \mathrm{~cm}^{-1}$ are formed (Fig. 4), which are assigned to coordinated $\mathrm{NH}_{3}$ adsorbed on Lewis acid sites [10]. In the $\mathrm{NH}$ vibration region, IR bands at 3160,3253 , and $3334 \mathrm{~cm}^{-1}$ are seen and are also assigned to coordinated $\mathrm{NH}_{3}$ bound to Lewis acid sites. The band at $1306 \mathrm{~cm}^{-1}$ is probably due to $\mathrm{NH}_{3}$ adsorbed on different Lewis sites [17]. At the same time, IR bands observed at 1458 and $1680 \mathrm{~cm}^{-1}$ are from asymmetric and symmetric deformations of $\mathrm{NH}_{4}{ }^{+}$on Brönsted acid sites. It seems that there are less Brönsted acid sites than Lewis acid sites on the $\mathrm{Ti}_{0.9} \mathrm{Mn}_{0.05} \mathrm{Fe}_{0.05} \mathrm{O}_{2-\delta}$ catalyst. It can also be seen that the intensity of the bands at 1188 and $1598 \mathrm{~cm}^{-1}$ are far stronger than those at 1458 and $1680 \mathrm{~cm}^{-1}$. Additionally, the two stronger bands reach their peak intensities after $\mathrm{NH}_{3}$ is saturated on the catalyst at $50{ }^{\circ} \mathrm{C}$.

All surface-adsorbed $\mathrm{NH}_{3}$ species are quite stable during subsequent purging with $\mathrm{N}_{2}$ at $50{ }^{\circ} \mathrm{C}$. The spectra of these surface species at different temperatures are also presented in Fig. 4. With increasing temperature, the intensity of the bands at 1188 and $1598 \mathrm{~cm}^{-1}$ drops off gradually. At $450{ }^{\circ} \mathrm{C}$, these bands still obviously exist. The intensities of the bands in the $3400-3100 \mathrm{~cm}^{-1}$ region also decrease slightly. Meanwhile, the intensities of the bands at 1458 and $1680 \mathrm{~cm}^{-1}$ decline drastically, and the band at $1458 \mathrm{~cm}^{-1}$ can no longer be observed above $200{ }^{\circ} \mathrm{C}$. These results demonstrate that $\mathrm{NH}_{3}$ desorbs at increased temperatures. Moreover, Brönsted acid sites have lower thermal stability than Lewis acid sites.

\subsubsection{Co-adsorption of $\mathrm{NH}_{3}+\mathrm{O}_{2}$}

In this experiment, the $\mathrm{Ti}_{0.9} \mathrm{Mn}_{0.05} \mathrm{Fe}_{0.05} \mathrm{O}_{2-\delta}$ catalyst is treated with $\mathrm{NH}_{3}+\mathrm{O}_{2}$ in the same way. Both $\mathrm{NH}_{4}{ }^{+}$ions and coordinated

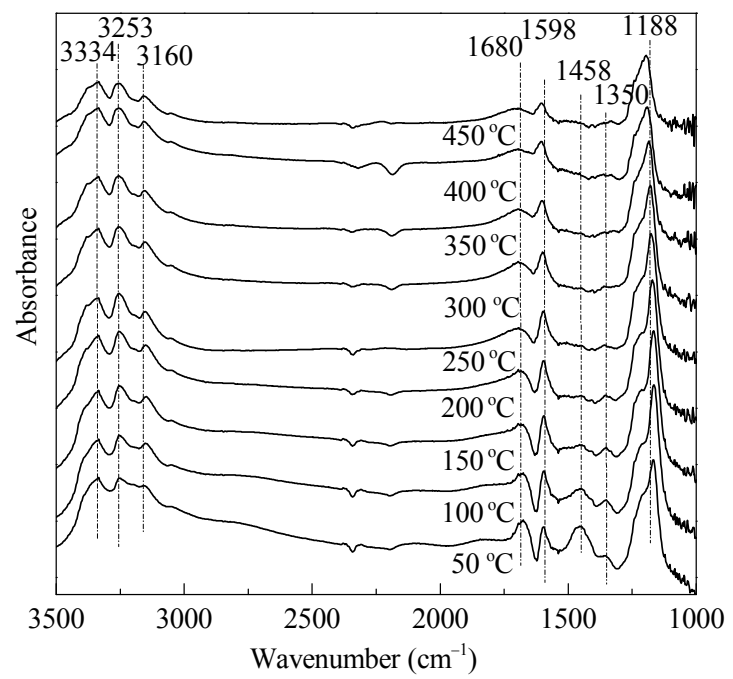

Fig. 4. In situ DRIFTS spectra of $\mathrm{Ti}_{0.9} \mathrm{Mn}_{0.05} \mathrm{Fe}_{0.05} \mathrm{O}_{2-\delta}$ during $\mathrm{NH}_{3}$ adsorption at different temperatures. Reaction conditions: $0.06 \% \mathrm{NH}_{3}, \mathrm{~N}_{2}$ as balance, total gas flow rate $50 \mathrm{~mL} / \mathrm{min}$.
$\mathrm{NH}_{3}$ are formed (Fig. 5). The intensities of the coordinated $\mathrm{NH}_{3}$ bands at 1188 and $1598 \mathrm{~cm}^{-1}$ decrease with increasing temperature as $\mathrm{NH}_{3}$ desorbs. However, when compared to the spectra of $\mathrm{NH}_{3}$ adsorbed on Lewis acid sites in Fig. 4, the variations between spectra at different temperatures are larger. The intensities of the bands at 1188 and $1598 \mathrm{~cm}^{-1}$ initially decrease gradually beginning at $150{ }^{\circ} \mathrm{C}$. When reaching a temperature of $450{ }^{\circ} \mathrm{C}$, the coordinated $\mathrm{NH}_{3}$ almost vanishes, without any obvious intensity. According to the literature [18], this may be caused by oxidation of $\mathrm{NH}_{3}$ to $\mathrm{NH}_{2}$ at a relatively low temperature range and oxidation of $\mathrm{NH}_{3}$ to $\mathrm{N}_{2}$ at a relatively high temperature. Additionally, a new band begins to appear at $1245 \mathrm{~cm}^{-1}$ at $400{ }^{\circ} \mathrm{C}$, which was attributed to a bridging nitrate. This nitrate could be due to side reactions taking place, yielding a certain amount of NO.

\subsubsection{Adsorption of NO}

NO adsorption measurements were performed in a feed of $0.06 \% \mathrm{NO}$ in $\mathrm{N}_{2}$ for $30 \mathrm{~min}$. The catalyst was then purged with $\mathrm{N}_{2}$ for $30 \mathrm{~min}$. Surface nitrate species are observed at 1245 , 1276, 1470, 1576, and $1612 \mathrm{~cm}^{-1}$ (Fig. 6). The IR band at 1245 $\mathrm{cm}^{-1}$ can be assigned to a bridging nitrate, and that at 1276 $\mathrm{cm}^{-1}$ and $1470 \mathrm{~cm}^{-1}$ are assigned to monodentate nitrate, while bands at $1576 \mathrm{~cm}^{-1}$ are attributed to bidentate nitrate. According to results of Long et al. [17], the band at $1612 \mathrm{~cm}^{-1}$ is not easy to assign. They assigned it to an $\mathrm{NO}_{2}$ adspecies (nitro or adsorbed $\mathrm{NO}_{2}$ molecule) on the catalyst, because this species had a different thermal stability from that of other nitrate species. It can be also seen that the species appeared at $1612 \mathrm{~cm}^{-1}$ exhibits a similar thermal stability as the bridging nitrate. Thus, we assign it to the bridging nitrate.

IR bands in these regions decrease with increasing temperature (Fig. 6), indicating desorption of NO. IR bands at 1276 and $1470 \mathrm{~cm}^{-1}$ show the most rapid disappearance, occurring at $200{ }^{\circ} \mathrm{C}$. The intensities of the bands at 1245 and $1612 \mathrm{~cm}^{-1}$

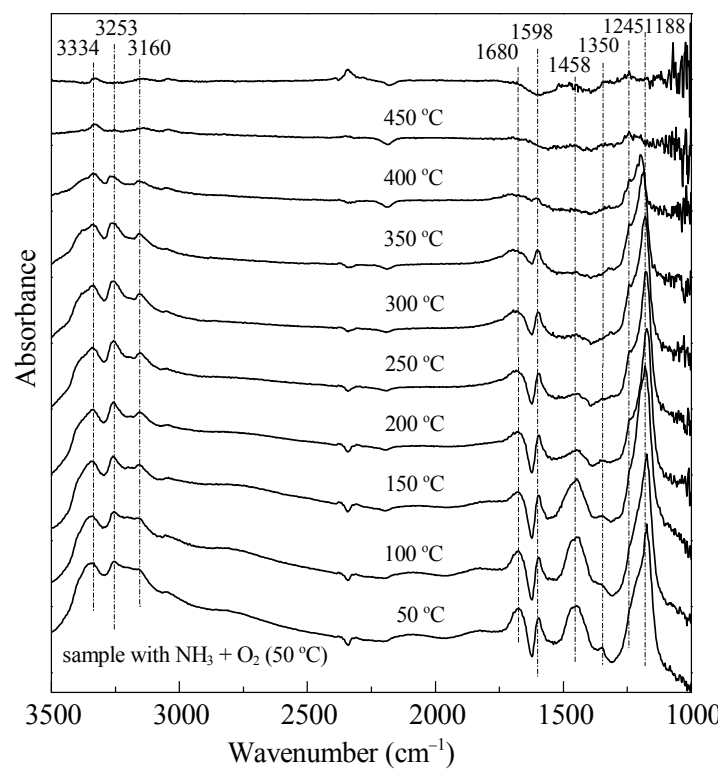

Fig. 5. In situ DRIFTS spectra of $\mathrm{Ti}_{0.9} \mathrm{Mn}_{0.05} \mathrm{Fe}_{0.05} \mathrm{O}_{2-\delta}$ during $\mathrm{NH}_{3}+\mathrm{O}_{2}$ adsorption at different temperatures. Reaction conditions: $0.06 \% \mathrm{NH}_{3}$, $5 \% \mathrm{O}_{2}, \mathrm{~N}_{2}$ as balance, and total gas flow rate $50 \mathrm{~mL} / \mathrm{min}$. 


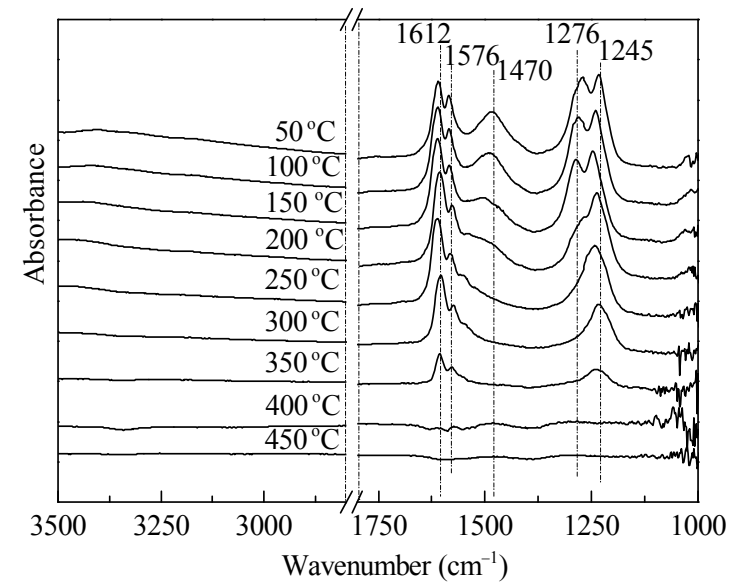

Fig. 6. In situ DRIFTS spectra for adsorption of NO over $\mathrm{Ti}_{0.9} \mathrm{Mn}_{0.05} \mathrm{Fe}_{0.05} \mathrm{O}_{2-\delta}$ at different temperatures. Reaction conditions: $0.06 \% \mathrm{NO}, \mathrm{N}_{2}$ as balance, and total gas flow rate $50 \mathrm{~mL} / \mathrm{min}$.

decrease slightly slower, such that they can still be observed at $350{ }^{\circ} \mathrm{C}$. The bidentate nitrate at $1576 \mathrm{~cm}^{-1}$ does not disappear until $450{ }^{\circ} \mathrm{C}$. The thermal stability of the nitrate species follows the order: bidentate nitrate $>$ bridging nitrate $>$ monodentate nitrate.

To investigate the influence of gaseous $\mathrm{O}_{2}$, we carried out the adsorption of $\mathrm{NO}$ and $\mathrm{NO}+\mathrm{O}_{2}$ over $\mathrm{Ti}_{0.9} \mathrm{Mn}_{0.05} \mathrm{Fe}_{0.05} \mathrm{O}_{2-\delta}$ at $150{ }^{\circ} \mathrm{C}$. First, the catalyst was treated with $\mathrm{NO}$ and $\mathrm{NO}+\mathrm{O}_{2}$ in $\mathrm{N}_{2}$ for 30 min, and then was purged with $\mathrm{N}_{2}$ for an extended 90 min. The recorded IR spectra are shown in Fig. 7. It is obvious that $\mathrm{NO}+\mathrm{O}_{2}$ adsorption is much stronger than $\mathrm{NO}$ adsorption because gaseous $\mathrm{O}_{2}$ could enhance the oxidation of $\mathrm{NO}$ to $\mathrm{NO}_{2}$, leading to the formation of surface nitrate species. In the NO only treatment case, oxidation of NO is simply caused by lattice oxygen. After purging with $\mathrm{N}_{2}$ for $90 \mathrm{~min}$, only a slight decrease in the intensities of the surface nitrate species bands is seen in the two cases, which implies that surface NO adsorption species are caused by fairly stable chemisorption, regardless of $\mathrm{O}_{2}$. This is consistent with results reported by Centi et al. [19], who proposed that chemisorption of NO on the catalyst copper sites was significant and that chemisorption is enhanced by the

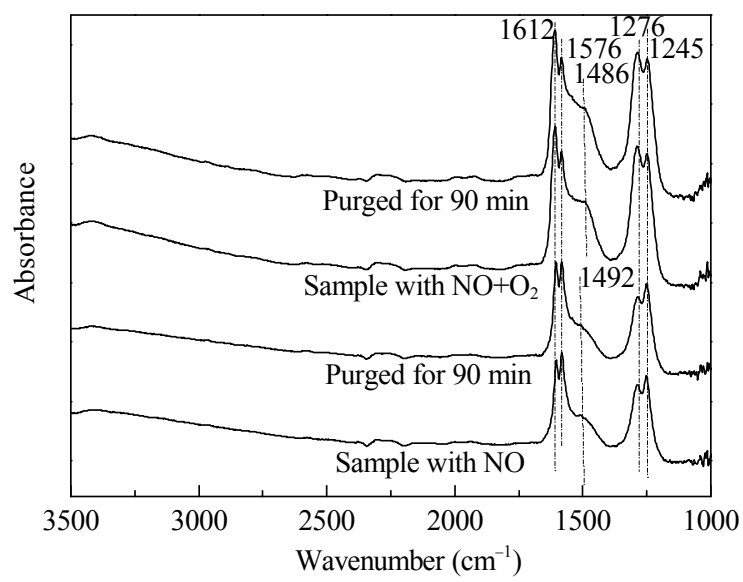

Fig. 7. In situ DRIFTS spectra for adsorption of NO over $\mathrm{Ti}_{0.9} \mathrm{Mn}_{0.05} \mathrm{Fe}_{0.05} \mathrm{O}_{2-\delta}$ with and without $\mathrm{O}_{2}$ at $150{ }^{\circ} \mathrm{C}$. Reaction conditions: $0.06 \% \mathrm{NO}, 5 \% \mathrm{O}_{2}, \mathrm{~N}_{2}$ as balance, total gas flow rate $50 \mathrm{~mL} / \mathrm{min}$. presence of oxygen.

\subsubsection{Reaction studies under transient conditions}

\subsubsection{Reaction between only $\mathrm{NO}$ and adsorbed $\mathrm{NH}_{3}$}

To investigate the reaction mechanism of SCR by $\mathrm{NH}_{3}$ over the $\mathrm{Ti}_{0.9} \mathrm{Mn}_{0.05} \mathrm{Fe}_{0.05} \mathrm{O}_{2-\delta}$ catalyst, the sample was first exposed to $\mathrm{NH}_{3}$ at $150{ }^{\circ} \mathrm{C}$ until it was saturated. The catalyst was then purged with $\mathrm{N}_{2}$ and subsequently exposed to NO. IR spectra were recorded as a function of time (Fig. 8). Because of exposure to $\mathrm{NH}_{3}$, IR bands assigned to coordinated $\mathrm{NH}_{3}$ or $\mathrm{NH}_{4}{ }^{+}$appear. However, after 70 min of NO exposure, no apparent decrease in the adsorbed $\mathrm{NH}_{3}$ is seen, and no surface NO adsorption species are seen to accumulate on the catalyst. At the same time, we could not find evidence for the formation of any new adsorption species. This can be explained from several aspects $[17,20,21]$. First, the absence of gaseous $\mathrm{O}_{2}$ inhibits NO oxidation, suppressing the formation of nitrate species. Additionally, our observations are possibly caused by competition between $\mathrm{NO}$ and $\mathrm{NH}_{3}$ for the same adsorption sites on the catalyst surface. Moreover, gaseous NO has a low reaction probability with adsorbed $\mathrm{NH}_{3}$, owing to lack of gaseous $\mathrm{O}_{2}$ in the reaction conditions. The activation of adsorbed $\mathrm{NH}_{3}$ by gaseous $\mathrm{O}_{2}$ to form $\mathrm{NH}_{2}$ is a main step in the catalytic mechanism.

\subsubsection{Reaction between gas mixtures $\mathrm{NO}+\mathrm{O}_{2}$ and adsorbed $\mathrm{NH}_{3}$}

For the case of reaction between $\mathrm{NO}+\mathrm{O}_{2}$ and adsorbed $\mathrm{NH}_{3}$, the catalyst sample was first exposed to $\mathrm{NH}_{3}$ at $150{ }^{\circ} \mathrm{C}$ until it was saturated, then purged with $\mathrm{N}_{2}$. After that, $\mathrm{NO}+\mathrm{O}_{2}$ was introduced into the cell. The results are shown in Fig. 9. IR bands at $1188,3160,1598$, and $3253 \mathrm{~cm}^{-1}$, assigned to coordinated $\mathrm{NH}_{3}$ on Lewis acid sites as noted above, decease gradually with time until they disappear. The vibrational signature of $\mathrm{NH}_{4}^{+}$on Brönsted acid sites at $1680 \mathrm{~cm}^{-1}$ vanishes quickly after exposure to NO for about $25 \mathrm{~min}$, indicating that NO rapidly reacts with adjacent adsorbed $\mathrm{NH}_{4}+25$ min later. Thus, it is suggested that both Brönsted and Lewis acid sites are involved in NO reduction.

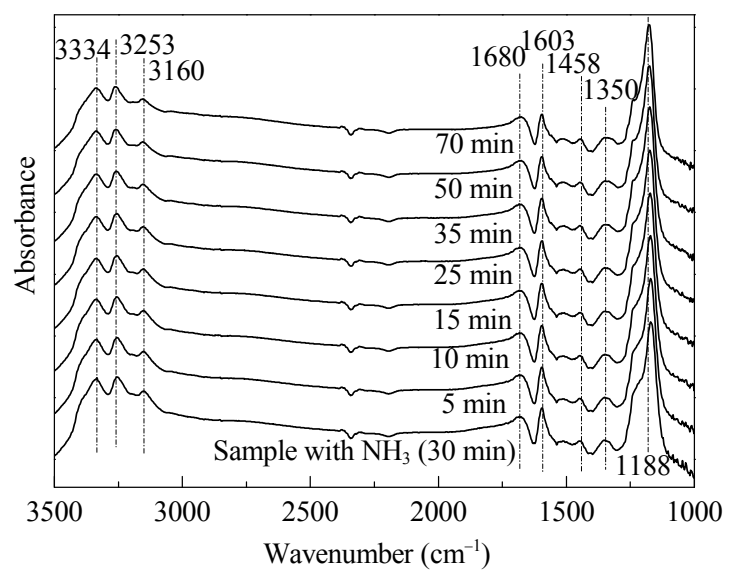

Fig. 8. In situ DRIFTS spectra of $\mathrm{Ti}_{0.9} \mathrm{Mn}_{0.05} \mathrm{Fe}_{0.05} \mathrm{O}_{2-\delta}$ during transient $\mathrm{NO}$ exposure after $\mathrm{NH}_{3}$ adsorption at $150{ }^{\circ} \mathrm{C}$. Reaction conditions: $0.06 \%$ $\mathrm{NO}, \mathrm{N}_{2}$ as balance, and total gas flow rate $50 \mathrm{~mL} / \mathrm{min}$. 


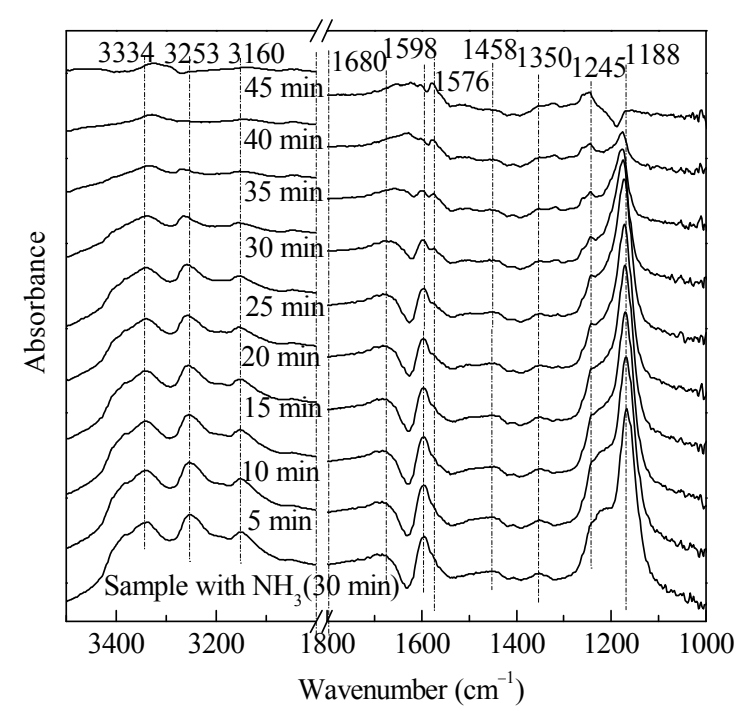

Fig. 9. In situ DRIFTS spectra of $\mathrm{Ti}_{0.9} \mathrm{Mn}_{0.05} \mathrm{Fe}_{0.05} \mathrm{O}_{2-\delta}$ during transient NO $+\mathrm{O}_{2}$ exposure after $\mathrm{NH}_{3}$ adsorption at $150{ }^{\circ} \mathrm{C}$. Reaction conditions: $0.06 \% \mathrm{NO}, 5 \% \mathrm{O}_{2}, \mathrm{~N}_{2}$ as balance, total gas flow rate $50 \mathrm{~mL} / \mathrm{min}$.

Some new species appear after 25 min of reaction. The band at $1245 \mathrm{~cm}^{-1}$ is assigned to low-frequency vibrations of a bridging nitrate, and the band at $1576 \mathrm{~cm}^{-1}$ is assigned to bidentate nitrate. The intensities of the bands at 1245 and 1576 $\mathrm{cm}^{-1}$ increase with time after their initial appearance. However, signals for the monodentate nitrate species at 1276 and 1470 $\mathrm{cm}^{-1}$ do not emerge, indicating that the monodentate nitrate on the $\mathrm{Ti}_{0.9} \mathrm{Mn}_{0.05} \mathrm{Fe}_{0.05} \mathrm{O}_{2-\delta}$ surface reacts with $\mathrm{NH}_{3}$ immediately preventing detectable concentrations to arise. The bridging nitrate and bidentate nitrate seem to be inactive for the SCR reaction. Hence, the monodentate nitrate is suggested to be a key intermediate.

Furthermore, it can be seen that the rate of SCR reaction becomes faster after $25 \mathrm{~min}$. For the competitive adsorption of $\mathrm{NO}$ and $\mathrm{NH}_{3}$ on the catalyst surface, no nitrate species formation is seen in the first $25 \mathrm{~min}$. Coordinated $\mathrm{NH}_{3}$ is first activated by active oxygen from the dehydration between manganese oxides, yielding the amide species from $\mathrm{H}$ abstraction [21]. At this point, the intermediate species $\mathrm{NH}_{2}$ further reacts with gaseous $\mathrm{NO}$ to form $\mathrm{N}_{2}$ and $\mathrm{H}_{2} \mathrm{O}$ following an E-R mechanism. Then as the adsorbed $\mathrm{NH}_{3}$ species are consumed, sufficient adsorption sites are available for NO. The SCR process then begins to follow a L-H mechanism, in which adsorbed $\mathrm{NH}_{4}{ }^{+}$and coordinated $\mathrm{NH}_{3}$ react with nitrate species. Comparing with the results presented in Section 3.3.4.1., it is clear that oxygen plays an important role in the reaction between $\mathrm{NO}$ and $\mathrm{NH}_{3}$ [21], as a result of the oxidation of $\mathrm{NH}_{3}$ and NO. At a low temperature $\left(150{ }^{\circ} \mathrm{C}\right)$, it is difficult to form $\mathrm{NH}_{2}$ species because of the high activation energy [20]. Conversely, NO oxidation occurs a little faster by the high oxidative ability of Mn. As more nitrate species adsorb, the reaction rate is accelerated. This is why the catalysts with Mn have outstanding low-temperature performance. As a result, at $150{ }^{\circ} \mathrm{C}$ both $\mathrm{L}-\mathrm{H}$ and $\mathrm{E}-\mathrm{R}$ mechanisms are involved in the SCR reaction, while the L-H mechanism is dominant for the $\mathrm{Ti}_{0.9} \mathrm{Mn}_{0.05} \mathrm{Fe}_{0.05} \mathrm{O}_{2-\delta}$ catalyst.

\subsubsection{Reaction between $\mathrm{NH}_{3}$ and adsorbed $\mathrm{NO}+\mathrm{O}_{2}$}

To investigate the reaction between $\mathrm{NH}_{3}$ and adsorbed gas mixture $\mathrm{NO}+\mathrm{O}_{2}$, the $\mathrm{Ti} 0.9 \mathrm{Mn}_{0.05} \mathrm{Fe}_{0.05} \mathrm{O}_{2-\delta}$ catalyst sample was first treated with gas mixtures $\mathrm{NO}+\mathrm{O}_{2}$ at $150{ }^{\circ} \mathrm{C}$ until it was saturated, followed by $\mathrm{N}_{2}$ purging. When the treated sample is exposed to $\mathrm{NH}_{3}$, the intensities of the bands at 1245, 1276, 1576 , and $1612 \mathrm{~cm}^{-1}$, assigned to surface nitrate species, decrease (Fig. 10). The band intensity for the bridging nitrate at $1245 \mathrm{~cm}^{-1}$ decreases quickly, disappearing within $15 \mathrm{~min}$, while the band intensity of the monodentate nitrate at 1276 $\mathrm{cm}^{-1}$ decreases slightly slower, disappearing after about $35 \mathrm{~min}$ of $\mathrm{NH}_{3}$ exposure. The bridging nitrate band at $1612 \mathrm{~cm}^{-1}$ can still be observed after 40 min. Exposure to $\mathrm{NH}_{3}$ results in little change to the band intensity of the bidentate nitrate at 1576 $\mathrm{cm}^{-1}$. These intensity changes for the nitrate species indicate that monodentate and bridging nitrates have high reactivities with $\mathrm{NH}_{3}$, while the bidentate nitrate seems to be little reactive towards $\mathrm{NH}_{3}$. This is consistent with the results of reaction between $\mathrm{NO}+\mathrm{O}_{2}$ and adsorbed $\mathrm{NH}_{3}$.

Meanwhile, IR bands at 1188, 1230, 1295, 1458, 1680, 3160, 3253 , and $3334 \mathrm{~cm}^{-1}$ emerge, belonging to a group of surface $\mathrm{NH}_{3}$ adsorption complexes on the $\mathrm{Ti}_{0.9} \mathrm{Mn}_{0.05} \mathrm{Fe}_{0.05} \mathrm{O}_{2-\delta}$ catalyst. The intensity of all these bands increases quickly within about $10 \mathrm{~min}$, because surface acid sites have a strong adsorption capacity of $\mathrm{NH}_{3}$ due to the effect of the active Fe metal [20]. The intensity of the band at $1188 \mathrm{~cm}^{-1}$ remains strong after $10 \mathrm{~min}$ exposure to $\mathrm{NH}_{3}$, suggesting continuous accumulation of coordinated $\mathrm{NH}_{3}$ on the catalyst. However, almost no changes are seen in the ionic $\mathrm{NH}_{4}+$ bands at 1458 and $1680 \mathrm{~cm}^{-1}$ after 10 min. New bands at 1230 and $1295 \mathrm{~cm}^{-1}$ are detected, and they increase with time in $\mathrm{NH}_{3}$ flow. So these bands could not be attributed to surface nitrate species. In contrast to the results of adsorbed $\mathrm{NH}_{3}$ shown in Fig. 4, no adsorbed species are seen at 1230 and $1295 \mathrm{~cm}^{-1}$ when the catalyst is first treated with $\mathrm{NH}_{3}$ and then purged by $\mathrm{N}_{2}$. Therefore, we assigned these bands to

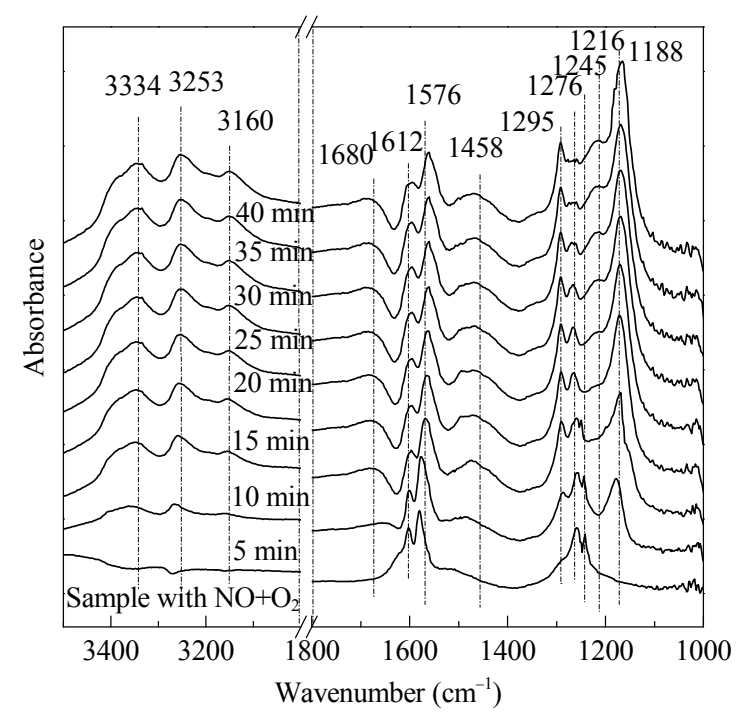

Fig. 10. In situ DRIFTS spectra of $\mathrm{NH}_{3}-\mathrm{SCR}$ reaction over $\mathrm{Ti}_{0.9} \mathrm{Mn}_{0.05} \mathrm{Fe}_{0.05} \mathrm{O}_{2-\delta}$ during transient $\mathrm{NH}_{3}$ exposure after $\mathrm{NO}+\mathrm{O}_{2}$ co-adsorption at $150{ }^{\circ} \mathrm{C}$. Reaction conditions: $0.06 \% \mathrm{NH}_{3}$ and $\mathrm{N}_{2}$ as balance, total gas flow rate $50 \mathrm{~mL} / \mathrm{min}$. 
weak adsorbed $\mathrm{NH}_{3}$ species.

On the basis of the above analysis, the $\mathrm{L}-\mathrm{H}$ mechanism is dominant for the $\mathrm{Ti}_{0.9} \mathrm{Mn}_{0.05} \mathrm{Fe}_{0.05} \mathrm{O}_{2-\delta}$ catalyst at $150{ }^{\circ} \mathrm{C}$, and both adsorbed $\mathrm{NH}_{4}{ }^{+}$and coordinated $\mathrm{NH}_{3}$ participate in the $\mathrm{L}-\mathrm{H}$ reaction path. During the reaction of $\mathrm{NH}_{3}$ and adsorbed $\mathrm{NO}+$ $\mathrm{O}_{2}$, surface $\mathrm{NH}_{4}{ }^{+}$on Brönsted acid sites remain stable, maintaining their intensity, probably because the rate of $\mathrm{NH}_{3}$ adsorption on Brönsted acid sites is equal to the rate of $\mathrm{NH}_{4}{ }^{+}$reaction with NO. The amount of coordinated $\mathrm{NH}_{3}$ on Lewis acid sites continues to increase due to the relatively slow rate of reaction between $\mathrm{NO}$ and coordinated $\mathrm{NH}_{3}$. This suggests that Brönsted acid sites are more active than Lewis acid sites on the $\mathrm{Ti}_{0.9} \mathrm{Mn}_{0.05} \mathrm{Fe}_{0.05} \mathrm{O}_{2-\delta}$ catalyst.

According to the results of in situ DRIFTS, the reaction mechanism can be deduced as following the reaction scheme depicted in equations (1)-(4):

$$
\begin{gathered}
\mathrm{M}^{n+}-\mathrm{O}-\mathrm{NO}_{2}+2 \mathrm{NH}_{4}^{+} \rightarrow \mathrm{M}^{n+}-\mathrm{O}-\mathrm{NO}_{2}\left[\mathrm{NH}_{4}^{+}\right]_{2} \\
\mathrm{M}^{n+}-\mathrm{O}-\mathrm{NO}_{2}+2 \mathrm{NH}_{3}(\mathrm{a}) \rightarrow \mathrm{M}^{n+}-\mathrm{O}-\mathrm{NO}_{2}\left[\mathrm{NH}_{3}\right]_{2} \\
\mathrm{M}^{n+}-\mathrm{O}-\mathrm{NO}_{2}\left[\mathrm{NH}_{4}^{+}\right]_{2}+\mathrm{NO} \rightarrow 2 \mathrm{~N}_{2}+3 \mathrm{H}_{2} \mathrm{O}+2 \mathrm{H}^{+}+\mathrm{M}^{n+}-\mathrm{O} \\
\mathrm{M}^{n+}-\mathrm{O}-\mathrm{NO}_{2}\left[\mathrm{NH}_{3}\right]_{2}+\mathrm{NO} \rightarrow \mathrm{N}_{2}+3 \mathrm{H}_{2} \mathrm{O}+\mathrm{M}^{n+}-\mathrm{O}
\end{gathered}
$$

The formation of monodentate nitrate $\mathrm{M}^{n+-} \mathrm{O}-\mathrm{NO}_{2}(\mathrm{M}=\mathrm{Fe}$ and $\mathrm{Mn}$ ) is involved in reaction with adsorbed $\mathrm{NH}_{4}{ }^{+}$or $\mathrm{NH}_{3}$ on neighboring acid sites, to produce an active intermediate $\mathrm{M}^{n+}-\mathrm{O}-\mathrm{NO}_{2}\left[\mathrm{NH}_{4}^{+}\right]_{2}$ or $\mathrm{M}^{n+}-\mathrm{O}-\mathrm{NO}_{2}\left[\mathrm{NH}_{3}\right]_{2}$, which finally reacts with gaseous $\mathrm{NO}$ to form $\mathrm{N}_{2}$ and $\mathrm{H}_{2} \mathrm{O}[17,20]$.

\section{Conclusions}

The $\mathrm{Ti}_{0.9} \mathrm{Mn}_{0.05} \mathrm{Fe}_{0.05} \mathrm{O}_{2-\delta}$ catalyst shows high SCR performance over a broad temperature window of $100-350{ }^{\circ} \mathrm{C}$. The active components of $\mathrm{Mn}$ and Fe exist in a highly dispersed state and amorphous form on $\mathrm{TiO}_{2}$. In situ DRIFTS measurements suggest that Brönsted and Lewis acid sites both take part in the SCR reaction, and Brönsted acid sites may play a more important role in determining the activity of $\mathrm{Ti}_{0.9} \mathrm{Mn}_{0.05} \mathrm{Fe}_{0.05} \mathrm{O}_{2-\delta}$. The monodentate nitrate species is key active intermediate, in comparison to the less important bridging and bidentate nitrate species. At $150{ }^{\circ} \mathrm{C}$, both $\mathrm{L}-\mathrm{H}$ mechanism and E-R mechanisms are involved in the SCR reaction, while the $\mathrm{L}-\mathrm{H}$ mechanism dominates catalytic activity of $\mathrm{Ti}_{0.9} \mathrm{Mn}_{0.05} \mathrm{Fe}_{0.05} \mathrm{O}_{2-\delta}$. The presence of $\mathrm{O}_{2}$ significantly affects $\mathrm{NO}$ oxidation and coordinated $\mathrm{NH}_{3}$ activation. Hence, at a low temperature, NO oxidation is a main step, which depends on the oxidative ability of the active metal.

\section{References}

[1] Balle P, Geiger B, Kureti S. Appl Catal B, 2009, 85: 109

[2] Devadas M, Kröcher O, Elsener M, Wokaun A, Mitrikas G, Söger N, Pfeifer M, Demel Y, Mussmann L. Catal Today, 2007, 119: 137

[3] Balle P, Geiger B, Klukowski D, Pignatelli M, Wohnrau S, Menzel M, Zirkwa I, Brunklaus G, Kureti S. Appl Catal B, 2009, 91: 587

[4] Ettireddy P R, Ettireddy N, Mamedov S, Boolchand P, Smirniotis P G. Appl Catal B, 2007, 76: 123

[5] Domingo J L. Reprod Toxicol, 1996, 10: 175

[6] Liu F D, He H, Ding Y, Zhang C B. Appl Catal B, 2009, 93: 194

[7] Liu F D, He H, Zhang C B, Feng Z C, Zheng L R, Xie Y N, Hu T D. Appl Catal B, 2010, 96: 408

[8] Roy S, Viswanath B, Hegde M S, Madras G. J Phys Chem C, 2008, 112: 6002

[9] Larrubia M A, Ramis G, Busca G. Appl Catal B, 2001, 30: 101

[10] Guan B, Lin H, Zhu L, Huang Z.J Phys Chem C, 2011, 115: 12850

[11] Biabani A, Rezaei M, Fattah Z. J Nat Gas Chem, 2012, 21: 415

[12] Qi G, Yang R T. Appl Catal B, 2003, 44: 217

[13] Zhou G Y, Zhong B C, Wang W H, Guan X J, Huang B C, Ye D Q, Wu H J. Catal Today, 2011, 175: 157

[14] Yang S J, Wang C Z, Li J H, Yan N Q, Ma L, Chang H Z. Appl Catal B, 2011, 110: 71

[15] Aruna S T, Mukasyan A M. Curr Opin Solid State Mater Sci, 2008, 12: 44

[16] Zhu L, He L Guan B, Huang Z. Vehicle Engine (朱霖, 林赫, 管斌, 黄

\section{Graphical Abstract}

Chin. J. Catal., 2014, 35: 294-301 doi: 10.1016/S1872-2067(12)60730-X

\section{In situ DRIFTS study of the mechanism of low temperature selective catalytic reduction over manganese-iron oxides}

Ting Chen, Bin Guan, He Lin*, Lin Zhu

Shanghai Jiao Tong University

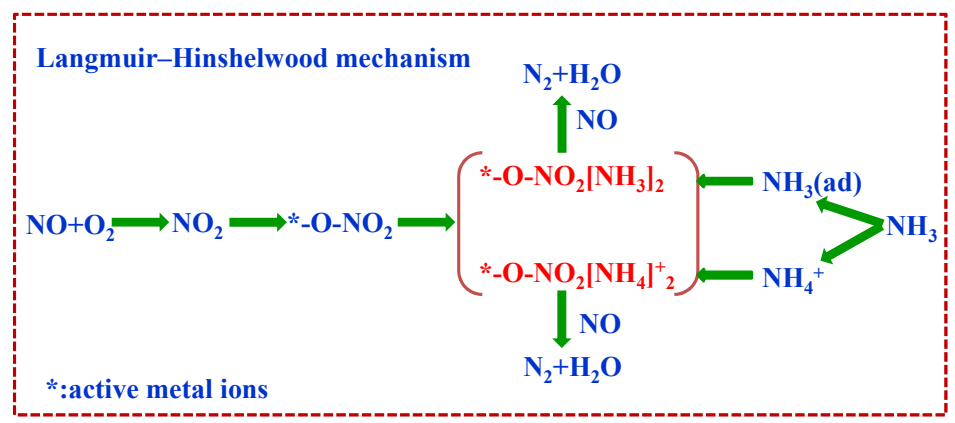

Selective catalytic reduction reactions over $\mathrm{Ti}_{0.9} \mathrm{Mn}_{0.05} \mathrm{Fe}_{0.05} \mathrm{O}_{2-\delta}$ catalysts possibly proceed according to both Langmuir-Hinshelwood and Eley-Rideal mechanisms, but NO more likely reacts as an adsorbed species. 
震. 车用发动机), 2012, (3): 72

[17] Long R Q, Yang R T. J Catal, 2000, 190: 22

[18] Kijlstra W S, Brands D S, Smit H I, Poels E K, Bliek A. J Catal, 1997, 171: 219
[19] Centi G, Perathoner S. J Catal, 1995, 152: 93

[20] Liu F D, He H, Zhang C B, Shan W P, Shi X Y. Catal Today, 2011, 175: 18

[21] Jiang B Q Li Z G, Lee S C. Chem Eng J, 2013, 225: 52

\title{
原位漫反射傅里叶变换红外光谱研究锰铁基催化剂上 低温选择性催化还原反应机理
}

\author{
陈 婷，管 斌，林 赫 ${ }^{*}$, 朱 霖 \\ 上海交通大学动力机械及工程教育部重点实验室, 上海 200240
}

摘要: 采用自蔓延燃烧法制备了 $\mathrm{Ti}_{0.9} \mathrm{Mn}_{0.05} \mathrm{Fe}_{0.05} \mathrm{O}_{2-\delta}$ 催化剂, 运用原位漫反射傅里叶变换红外光谱对该催化剂的 $\mathrm{NO}$ 和 $\mathrm{NH}_{3}$ 稳态吸 附以及 $\mathrm{NO}$ 和 $\mathrm{NH}_{3}$ 瞬态反应进行了详细地分析与讨论. 结果表明, 相比于Lewis酸性位, $150{ }^{\circ} \mathrm{C}$ 时Brönsted酸性位吸附的 $\mathrm{NH}_{3}$ 更具有 SCR 活性; 与双齿硝酸盐和桥式硝酸盐相比, NO吸附产生的单齿硝酸盐是主要的中间物种; 该SCR反应遵循Eley-Rideal和 Langmuir-Hinshelwood机理, 但以后者为主. 另外, $\mathrm{O}_{2}$ 的存在有利于 $\mathrm{NO}$ 的氧化和配位态 $\mathrm{NH}_{3}$ 的活化.

关键词: 氮氧化物; 氨; 镇铁基催化剂; 低温选择性催化还原; 原位漫反射傅里叶变换红外光谱

收稿日期: 2013-08-21. 接受日期: 2013-10-15. 出版日期: 2014-03-20.

*通讯联系人. 电话: (021)34207774; 电子信箱: linhe@sjtu.edu.cn

基金来源：国家自然科学基金(51176118, 51306115); 中国博士后科学基金(2012M520894, 2013T60445).

本文的英文电子版由Elsevier出版社在ScienceDirect上出版(http://www.sciencedirect.com/science/journal/18722067). 